\title{
Third Gender Recognition: Identity And Social Interaction Issues Of Khawaja Saras In Pakistani Society
}

\author{
Mamoon Khan Khattak \\ \& \\ Ehtisham Ul Haq \\ Department of Social Work \& Sociology \\ Kohat University of Science \& Technology (KUST)
}

\begin{abstract}
The core purpose of this study was to bring forth the gender identity and social interaction issues of Khawaja Saras in Pakistani society. For this purpose a number of 15 khwaja saras were interviewed within their social environment to understand phenomena contextually, as spirit of qualitative nature of study. An interview guide was prepared to assist primary data collection process. The research found that khawaja saras do face gender identity and social interaction issues in Pakistani society. They perceived that society do give them lesser respect and social acceptance, therefore they feel socially isolated to a significant extent. It is recommended that society shall be made aware and motivated at large to accept khawaja saras as respectable third gender. There is a greater need of inculcating confidence and motivation among khawaja saras to live within mainstream society while making their social conditions favourable and by creating a respectable space for themselves through refined habits, improved human conduct and developed personality.
\end{abstract}

Keywords: Khawaja Sara, Gender Identity, Interaction, Society.

$$
\begin{aligned}
& \text { تلخيص }
\end{aligned}
$$

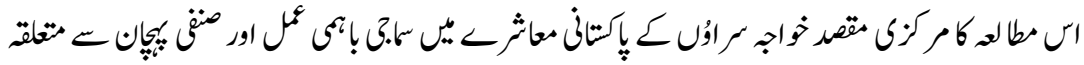

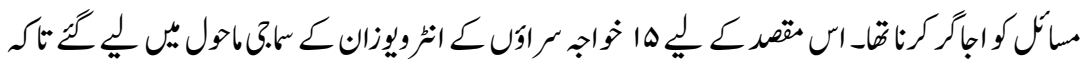

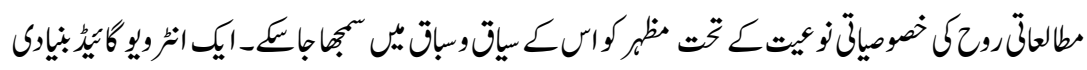

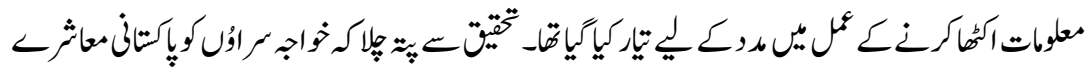

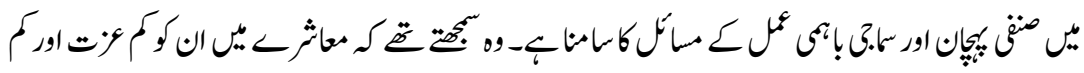

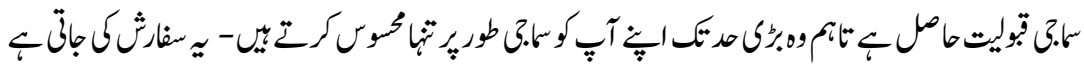

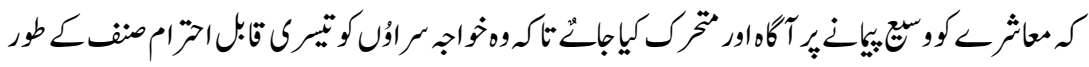




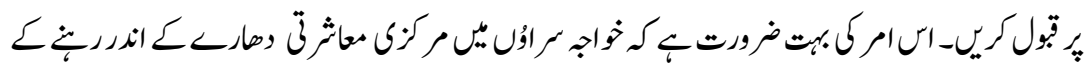

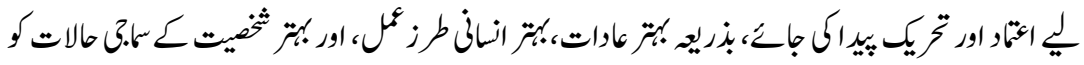

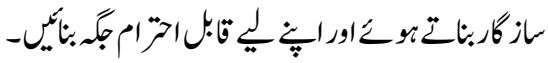

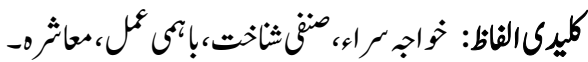

\section{Introduction}

Allah Almighty says it in the Holy Qur'an that creation of human and birth of child with a gender is His dominion which is explicit in the verse:

"To Allah belongs the kingdom of the heavens and the earth. He creates what He wills. He bestows female (offspring) upon whom He wills, and bestows male (offspring) upon whom He wills. 50. Or He bestows both males and females, and He renders barren whom He wills. Verily, He is the All-Knower and is Able to do all things. (Quran: Surah Al-Shura, Ayat 49-50)."

This verse clarifies that child's birth and his/her biological sex is determined solely by Allah Almighty, leaving no authority with human being. The human being cannot take birth by chance and cannot be born with biological sex of his/her own choice, except through will of Allah Almighty. The third gender's biological sex is also determined by Allah Almighty, and the believers shall accept this gender wholeheartedly. People generally deal third gender variably and as a result third gender faces a number of social and psychological issues. The gender is the socio-cultural construct regarding allocation of roles and responsibilities to individuals based on their biological sex, in a particular society. Hence, this fact is not ignorable that a paricular physical state and construct can perform only that roles which are possible for them, as an example, a male can never give birth to a child, only female do, this is determined by Allah Almighty. Holy Prophet Muhammad Peace Be Upon Him has cursed those whosoever shapes one's personality against one's biological sex, with which one is blessed by Allah Almighty. Which is explicit in the following Hadiths:-

"The Messenger of God, Peace Be Upon Him, cursed femaleimpersonators [m.pl.] who are males, and male-impersonators [f.pl.] who are women. (Al-Bukhari, vol.7, book.72, no.773)

"The Prophet, Peace Be Upon Him, cursed the effeminate men [m.pl.] who are males, and the male-pretenders [f.pl.] who are women, and he said: Evict them from your houses, and the 


\section{Prophet, Peace Be Upon Him, evicted such-and-such [m.sg.] and 'Umar evicted such-and-such [f.sg.]. (Al-Bukhari, vol.7, book.72, no.774)}

The main aim of study was to analyse diversities related to gender identity of khawaja saras in Pakistani society and to understand their social circumstances, social interaction patterns and social problems. It was hypothesized that khawaja sara experience social exclusion and isolation from mainstream society. Compared with other social problems, people generally are less concerned and less aware about internal life of this community and had lack of knowledge regarding their vulnerabilities. They, to some extent know the visible side of their presence in society, while having lesser familiarity to their internal and communal life. There are also fewer studies available exploring social interaction patterns and social situations of hijra community.

\section{Literature Review}

The exact meaning of hijra (khawaja sara) is quite hard to express in English, nevertheless, "the broadly used English translations of term "hijra", that is of Urdu in origin, could be described as either 'eunuch' or 'hermaphrodite' (intersex) connoting as impotence, indicating incapability to fulfil in male sexual role”. Hence, 'eunuch' denotes to an powerless male of whom genitals are vaguely male-like at birth time and have been formerly assigned to male sex, would be recategorized as intersexes or hijra (Nanda 1999). Being third sex, Khawaja Saras consider themselves neither male nor female, which may include impotent men, infertile women, hermaphrodites/intersex and eunuchs. Khawaja sara are do known as Hijra, Kinnar, Jogta, Jogappa, Khusra, Mohar Chanda, Manat and zanana etc. mostly dress and live resembling to women. Many pysiologically men Hijras' may pass through a revered procedure of castration called as "nirvan" or sex relocation surgery. According to an estimate, there are nearly 6 million Indians that identify themselves as Hijras (kumar, 2015). And more than a million and half transgender (khawajasaras/hijras) reside in Pakistan, pass through vulnerability due to common un-acceptance and seclusion from society, often experience repulsion by their family-members and subsequently are forced to join their companions in interwoven hijra communities (Chaudhry, et al., 2014).

Kessler \& McKenna (1978) stated that sex is biological component of human being, while gender is socio-psychological component. Hence, there are some circumstances in which biological characteristics contradicting the sociopsychological gender aspects, overriding biology in shaping gender identity and prompting gender role. Farid et al. (2013) said that hijras are conventional to 
gender in society, they are frequently transgender (male convert to female or the other way around); their outlook does construct controversy among individuals and between sexes in society. There already persist role and status conflict between two sexes (female/male) in society; therefore they are seldom agree to sanction entrance of novel sex (a third one) with novel status and roles. This unawareness starts a novel controversy in society because of reason that they try to seek adjustment, facing societal maladjustment, confronting with disrespect, isolation and ignorance etc. from culture and society. That adverse attitude in relation to hijras creates a number of psychosocial problems for them. Bartlett, Vasey and Bukowski (2000) argues that in certain cultures they are accepted as neither male nor female and not essentially be termed as deviant as they possess good social status. Udry (1994) describes gender as the series of features relating to, and differing between femininity and masculinity. Based on context, these features may include psychological sex i.e. condition of being female, male, or intersex; social structures based on sex including social roles, gender roles and gender identity etc. however, some cultures have particular gender-based social roles and can be considered dissimilar from female and male, for example, hijra of Pakistan and India. According to Chakrapani (2010), hijra are biologically males but refuse their masculine identity in due course of time to identify as 'women' or 'not men'. As hijra usually identify themselves as 'not men'. Expressed by Hahm (2010), hijra are those who are intersex by birth and can live as both male and female. On the other hand, hijra could be male who have undergone emasculation or wish to undergo emasculation and live as women. Talwar (1999) says that hijra is a distinctive gender type role appearance in Pakistan where male behaves as female; individuals refer to as acting like hijra, but not as a female. Expression hijra is mostly recognized as abuse for a male that is womanly, whimsical, impotent, ineffective or effeminate. Ali (2003) and Zafar (2004) talked that hijra in Pakistan are the individuals who are born with sexual deformity.

The males wearing female-like clothes are also termed as hijras (Bartlett, et al., 2000). The transgender or cross-dresser do also fall in the category of hijra, are named Zananay and persons castrated are termed as Narban (sacrificing man, a Persian word) considered equivalent to Khusra, post attaining asexuality through castration. They assert that a female soul is fenced in their bodies from birth time which stimulates them to act like females, but men who have joined hijra community persist to be veiled in society. They cross dress however are categorized as Zananay too, hence they are proven dissimilar from transvestites who cross-dress only (Ali, 2003 \& Zafar, 2004). Due to cross-dressing, eventually hijra are excluded from their family. Their female attitudes become barriers for their progress in school and work, and are often abused. They have a restricted 
access in knowledge and health service because of their lower literacy and economic status (Chakrapani, 2010). Zafar (2004) says that hijras do conceal their identity; their identity is covered in mythologies and untrue depiction, once depicting identity of intersexes/hermaphrodite by claiming as third gender, then as men depict womanhood by pretending woman's role. Hence wide population trust that hijras are persons born with sex related deformities. Though portraying womanhood they in majority still are not ready to indicate female sex in their identity papers. Pakistan's society is patriarchal; birth of male children is honoured by family comparing with female children's birth. Hijras take part in festivities at male children's birth, males/sons' marriages only and prefer to identify themselves with males in identity papers. Talwar (1999) argued that hijras trace their cultural lineage from Mughal era's khawaja saras, who were hermaphrodites or eunuchs employed as care takers by Mughal rulers (as guards, cleaners, cooks, message-deliverers etc.) of their harems. They played vital roles in courts, held significant authority state-affairs, and also represented as intimates of their masters. As end of princely rulers their socio-economic circumstances declined making them beggars.

Islam give equal opportunities and rights to all, while imposing certain restrictions on those who disobey and disrupt the conjunctions demarcated in Holy Qur'an and in Hadiths of Holy Prophet Muhammad Peace Be Upon Him. In Islam, the gender/sex is accepted as female and male only. If a child is born with sexual deformity is termed as Mukhanath or Khunsa (hermaphrodite) is socialized as either male or female depending on one's prominent physical traits. In some cases, sexual deformity is not noticeable sufficiently that it becomes hard to allocate any sex to child is then called as Khunsa-e-Mushkil (intersexed), however, necessity is there to allocate sex on analyzing urination system and sexual organs, in relation to male and female. Else it is prior to allocate female sex to sustain honour and confidentiality of individual (Badae, 1995). Sexual abnormality is same as other physical deformities that do not affect other physical and mental faculties of persons. The Intersex/ Hermaphrodite are given equal rights in Islam like other human beings (Badae, 1995). Pakistan has recently recognized legal status of hijras as third gender category (Teh, 2001). Quite recently, hijras have attained third gender status at the State level in Pakistan (Jami, \& Kamal, 2015). Implemented in January 2011 (National Data Base Registration Authority [NADRA], Dec 16, 2010) after Supreme Court of Pakistan ordered to exercise fair behaviour with hijras (Abid, 2009) and to create employment opportunities to which various organizations complied (Economic Times, Dec 23, 2009; NADRA, Dec 16, 2010). Mainstreaming of hijras is evident in Pakistani electronic media through talk shows and dramas etc. leading toward their acceptance in society. For the first time in 2013 hijras participated as candidates and voters in general elections for 
National and Provincial Assembly in Pakistan with their third gender status (Burke, 2013).

In Pakistan, khawaja saras face discrimination, abuse, and problems regarding basic human rights, for example, related to education, health care and employment etc. Their conditions were painful until Supreme Court given ruling in 2009 allowing khawaja saras for registering themselves on National Identity Cards as transgendered and having franchise (right to vote) in general elections (Rasul, 2012). The persistent repulsion and discrimination for transgender community has kept them involved in social evils and in poverty condition. Mostly they are mocked and teased if they make efforts for a better living (Sustainable Development Policy Institute, 2014). Gibbons, Stiles and Shkodriani (1991) said that gender roles in Pakistani community are mostly defined. While, Nanda (1986) found that family members and relatives play a significant role in developing individual's personality, and deficiency in family's assistance can lead to many social and psychological issues, majority hijras deprive of contacting with their original families. Talwar (1999) states that the treatment with hijras in Pakistan is found as somehow discriminatory. They are deprived of employment quotas as per their disability (if there is some), deprived of educational opportunities because of people's attitude. There is a need to re-understand them and sort out solution to their problems, however community give them charity, to get prays and good wishes, hence by and large people lesser like interacting with them.

\section{Research Methodology}

\section{Focus of Study}

The core objective of this study was to know that how do khawaja sara perceive about their social identity and their place in society, their interaction's pattern within society and societal response toward them. The study also aimed to propose solutions based on findings for making khawaja saras' survival optimal in society.

\section{Sampling, Data Collection and Data Analysis}

The study is qualitative in nature comprising of 15 in-depth interviews conducted in Kohat, Khyber Pakhtunkhwa, Islamic Republic of Pakistan, from September 2014 to February 2015. The data was transcribed and main themes were known regarding social interaction of khawaja sara in society. The respondents of study population belonged to District Mardan, Nowshera, Swat, Lahore and Islamabad; hence they were residing in Kohat city. The interview guide was comprised of 
such questions that covered gender identity and social interaction aspects of their lives.

\section{Ethical Considerations}

With their permission, khawaja saras (respondents) were briefed about research oriented purpose of visit which will discover and highlight their real life circumstances to society. They were assured about their confidentiality and their assented permission was sought before conduct of qualitative interviews.

\section{Qualitative Analysis of Primary Data: Field Observation and Field Interaction}

\section{Preliminary Ice-Breaking Interaction}

The justification of conducting research study on this phenomenon was the reason that there are a number of contemporary prevailing problems being faced by khawaja saras in society, some problems were related with their personal life spheres while others were related with their social life. The focus of study has been on their gender identity and social interaction issues in Pakistani society. They were living within this society and understood it well. The qualitative method was used for this study and sampling area was District Kohat of Khyber Pakhtunkhwa, Pakistan. As the researchers approached living place of hijra group (not mentioned due to research ethics, due to the element of confidentiality), at first instance they got astonished, surprised and hesitated to give interview. They were briefed about purpose of visit of researchers i.e. to conduct research on khawaja sara issues for which their cooperation was necessary in giving in depth primary data interviews based on their true views, feelings, experiences and emotional state. They expressed their anger regarding Govt. and local leaders who made promises with them of giving them a dignified and respectable place in every aspect of their life, but they did nothing visible in this regard till date. They told that they do realize that Pakistan is facing a number of serious and significant challenges of all types, hence Govt. shall not ignore them because they are its citizens and segment of its human society. They also mentioned that nobody ever came here to conduct such research for understanding their problems in their context and to bring forth it to mainstream society, to Govt. and to development organizations. Regarding research they were taken into confidence and were told that this research will raise their voice and will be a written communication from their side with society. It will also give opportunity and an advantage to society to understand khawaja saras experiences, feelings and viewpoints etc. for which communication is necessary with them, while community people mostly avoid 
meeting them due to social stigma attached to them. They were convinced hence a mild level psychological strain was observed at start and they somehow hesitated to give replies to questions openly. Hence, after brainstorming and taking them into confidence through communication they were convinced regarding research oriented purpose of meeting that is intended to communicate and transmit their voice, conditions, experiences and sufferings to rest of society, as a result society will understand them realistically to a greater degree.

\section{Primary Data Transcription}

Respondents shared regarding their gender identity that their such physiological condition was by nature, they did not made any operation for alteration or modification to their biological sex i.e. they are not transgender. They shared that they dress like females and they have feelings like females, therefore they identify themselves nearer to females. They are also fond of make-up and they do shape themselves as females through make-up. They were asked that if they were given chance of re-birth by Allah Almighty then which gender they will prefer to choose for themselves i.e. male, female or third gender, they replied that they would like to be created as females; hence it is the total discretion of Allah Almighty. According to primary data collected in field, none among respondents were local. They told that their family want to maintain relationship with them, but due to odd behaviour of society they themselves do not want that people may disrespect their parents. They told that nobody wants to leave their children who need parental care and they are in needful situation too. They expressed an intimate relationship with their parents which is quite internal and natural, hence problem is of social stigma that is attached to their physiological formation, not to the parents or individuals' feelings. They shared that they are linked and attached to their families, and if they do singing and dancing in their parents' or families' localities, it will disgrace them. They emphatically said that they do not want to disgrace their families.

They shared it as their parental respect's maintenance is a major reason that they alienate themselves from their families. They told that if certain disrespect or disgrace is attached to their families, then no one will have social relations with them. It is a social construct or due to cultural construct of strictness and patriarchy in which there is less room for them as third gender i.e. for males in relation to males, as males and females have, they do not have a defined or worked out role. In addition to these they also said that the society oddly think and perceive, therefore they cannot live or closely interact with their families. They do not want that their families may be disrespected or disgraced. Here, it is deduced that there is nothing wrong with physiological construct, rather it is the socio-cultural construct of society, of which the khawaja saras are also part, which forcefully alienate third gender and pushes them out from mainstream society, 
therefore they detach their identity from that of their parents and families. They miss their parents and feel socially secluded from their natural/blood relatives. They shared that their family members do not meet them and they feel loneliness as a result. They told that though they are physically detached from their parentalfamilies, hence they still love their families having good wishes for them, and expect that someday their family members may come to meet them. They shared that they sing and dance to earn in a place where it brings no harm to social respect of their families and they attach and identify themselves with such a group who have common gender (third one) based on unique physiological characteristics. They transform their identity to a next identity of a group of which they become members (and are intact) with an integrated khawaja sara-family and in this way they leave family and transform their relationship developing a new identity, becoming members of khawaja sara group, they told that this is their compulsion. They told that when they want to live with their families, people often criticize and tease their families. Regarding question on music programmes in their native localities, they said that it create problems for them and for their families, due to this reason they perform it away from their native localities. They told that due to their singing and dancing i.e. prohibited in Islam, which they realize too, is participated and shared by the society's segments at different occasions, hence they consider only khawaja saras as disrespectful members. They said that due to people's attitude i.e. starring and negative response, it become difficult for their family members to go out in public places, therefore they leave their families.

Regarding question on their contentment with their identity and status in society, they shared that they firmly believe that their gender has been determined by Allah Almighty and they are the creature of Allah Almighty, Who has created all creatures and Allah Almighty love all His creatures. They are thankful to Allah Almighty that He has created them as human being, the masterpiece of His creation. They were contented with their condition as third gender because Allah Almighty has created them, and in Allah Almighty's every creation there is a valuable secret and invaluable objective. They told that however other human being have no right to tease them, exploit them or disgrace them, as like other human being they possess all fundamental human rights. They expressed great contentment from their biological self with an evident thankfulness to Allah Almighty on their status-quo's creation; hence they were unhappy with the people's odd attitude. They shared their feeling that Allah Almighty has created them with such biological condition, they have no fault in it, if Allah Almighty has had created you (community people) in such condition, then what you could have done, and what expectations you would have had from rest of the society.

They live in a common place with great love, affection and respect for each other. They shared that they live collectively under the care and guardianship of a Guru 
(Master/Elder) who guide and protect them. While in relation to Guru, they are called as Chailas (Pupils/Dependants/Followers). They shared that in their third gender community they have no blood relation but they have a strong socioemotional bond with each other and consider each other as integral part of their family. Regarding question about any union or political party they shared that they have a President who is working for their rights, who also talk to government and communities. They shared that even the khawaja sara children of very respectable members of society are just like them and are living like them due to their gender identity. They respect their elders and they love and are kind to their youngsters as Holy Prophet Muhammad Peace Be Upon Him has said in following Hadith:-

"Anas bin Malik narrated: "An older man came to talk to The Holy Prophet Muhammad Peace Be Upon Him and people were hesitant to make room for him. The Prophet Peace Be Upon Him said: 'He is not one of us who does not have mercy on our young and does not respect our elders"," (Al-Tirmidhi, vol.4, ch.5, no. 1919).

Regarding their social interaction, it was known through in-depth interviews that khawaja saras face multiple problems in society as the normal people do also face, hence their issues are specific to their gender. They shared their experience that people generally perceive them as insignificant segments of society; hence they do not have special problems at all and have no problems of severe nature from society's side. They shared that community perceive that they do not want to change themselves and do lack will of becoming productive members of society, hence in actual they want to live a respectable life. The respondents shared that while interacting with society, they find improper response from individuals and some among them even do not consider khawaja saras as respectable members of society. Upon going to public places, sometimes they experience annoying remarks directed toward them. The social situation and cultural atmosphere somehow side line them and push them towards mental and social seclusion, where in as a result they gather, unite and develop their third gender communities. In mainstream society, no male or female can marry them due to their gender identity, physiological characteristics, psychological and social experiences, which is accepted only by their own gender. It is well said that when outer group do behave improperly, it cause the integration among members of in-group having unique characteristics. Now they raise voice for their own third gender's rights and they tell people that they can become productive members of society if they are given with needful opportunities.

Telling about their daily routine and day-to-day interaction, going to market, they told that society have different kind of people, some are good, some are bad; good people consider them as normal people and part of society and respect them 
much. While some people tease them by uttering different abusive voices. They shared that when they need daily usage items, often they made somebody else go to market for bringing it and in this way they meet their needs. All people do not treat them in similar manner necessarily by showing a passivity and subjectivity toward their lives, hence, they shared that a number of people give them a very accommodating and conducive social space, listen them carefully, giving them value, however some others make it difficult for them to pass through public places even. With passage of time, events and experiences they get used to it and are mentally ready, hence it is bare fact too that it hurts their feelings, sentiments, emotions and personal ego. They shared that some time they think and their mind generate question that unto when society will start treating them in a humanly civilized manner, as the society yet may have to be educated and civilized. The respondents shared that people who do act and behave discriminately with third gender, they may not be doing it wilfully, rather this might be due to their low level of maturity, socialization, education and awareness. They shared that some activists criticize society on part of third gender and even forget their positivity and supportive behaviour with them, which is clearly wrong; on humble aspect of society, it is the society which helps them, give them charities, meals and living places etc.

Upon morality's standpoint, they shared that they earn their livelihood and pass their time through singing and dancing which is often wrongly linked to prostitution, other blames upon them includes human trafficking, drugs addiction and trafficking, which are wrong too. They shared that the prostitution is a religious-social sin and a crime with a high level stigma and moral defaming which shall not be associated to being khawaja saras compulsorily, rather it is understood a sinful and criminal act disrupting religious-social and legal order of society, whosoever do it, shall be blamed and defamed, not whole of community to which one belongs i.e. males' community, females' community or khawaja saras' community. They shared that the community shall be known the Allah's displeasure regarding falsely blaming any believer with moral or other conduct's flaw. Islam considers morality-blame (tuhmat) on someone as a greater sin, and he/she who blame others falsely for immoralities, are considered as sinful, as is mentioned in the following verse:-

"And those who hurt the believing men and believing women without doing anything, they have taken over their heads a calumny and an open sin." (Al-Qur'an, Surah Al-Ahzab, Ayat 58).

Hence, there are community's wrongful apprehensions that they are morally bad people or criminals. The Allah Almighty has said it in the Holy Qur'an that everyone is born innocent and on truthful nature. The human's law too says that every citizen or person do have all fundamental rights, is respectable and innocent citizen until and unless a crime/guilt is proven against him/her. 
Regarding their economic status, they shared that they earn their livelihood and pass their time through singing and dancing at wedding and other social gatherings. In Holy month of Ramzan, wherein Muslims do fasting, being Muslims they do fasting too and as a result have no programmes and they have no earnings. They shared that when they do programmes then get money for fulfilling their needs, while when they do not do programmes as in case of holy month of fasting they remain in shortage of money that make them unable to pay even house rent and to meet routine expenditures, consequently house owner vacate house from them and they remain without house roaming for many days, even months. They also shared their worries related to their declining age that affect their demand in musical programmes, consequently they may become poor. Regarding question about their status they admitted that they themselves and society too limited them up to singing and dancing. They also want respectful jobs, want to live with their families but feel sorry for limiting themselves up to singing and dancing, except that they have nothing. They told that if their families start accepting them, then reciprocally the society will start accepting them as respectable members, Insha Allah. The detachment from father's family cause deprivation from parental/family's economic support and father's legacy, which make them poor, weak and dependent. They were asked about what kind of profession they want to adopt and why if they are provided with opportunity? They replied that they are more active, enthusiastic than other people and can do almost any kind of lawful and respectable job as other people do like labour in workshop, employment in private and public sector organizations etc., hence with social respect, acceptance and security. Regarding parents' profession or identity they did not clearly answered. They shared their intention of serving society and developing their country as its stakeholders. They can be very responsible and productive members of society if provided with appropriate opportunities and legal protection.

Upon question regarding education status, some were found as illiterate and some were educated up to Matric but due to their identity issues they could not continue their education process up to higher classes. In School, they reported the attitude of teachers as positive, however due to people attitude they remain unable to continue education and become dependent on society. The peer's atmosphere and going to and coming from school, the environment was in-conducive due to which they could not continue education up to higher classes and got less representation in education institutions. On query regarding health issues they shared that generally they have good health conditions. They shared that whenever they are ill, they go for treatment, and the doctor, especially female doctor, treat them very effectively, in respectful manner, very carefully, changing minor treatment fee. Hence at hospital etc. where there is public gathering, they have to face teasing remarks. Upon question on security issues, they told that they avoid going to police station for complaints. Hence regarding police behaviour they shared that they give them significant protection and in case someone tease them at their home or outside, on report, police come and rescue them. 
Regarding their religious affiliations and practices, they replied with humbleness that they are Muslims, they offer prayers daily and remain on fasting in Ramzan, and if could afford offering Hajj, they do perform Hajj as well. They told that they go to Masjid (Mosque). Eid Gah (Eid Prayer Place), Janaza Gah (Funeral Prayer Place) for offering prayers. This social group shall be viewed in Islamic perspective, Islam give them respectable human's status in society. Islam even do specify for prayer in congregation in sequence that the first row is for males/elders, second row is for children, third row is for females and fourth row is for khunsa (khawaja saras). Regarding question about funeral ceremony; they shared that it is conducted and joined by their community families and others, as funeral of Muslim is done in routine, considering them as much social as other people are. Wherein people respect them much and give them place in front row of Jamat (congregation/collective prayer in Mosque) and give very good response, but soon after when they come out of Masjid people do not express much respect toward them. Outside Masjid some individuals start mischievous actions teasing them, which makes them feel annoyed and force to think that why the same people give them respect inside Masjid and behave differently outside Masjid? They further shared their thinking that our God-The Allah Almighty is "One", we are followers of One God, One Holy Prophet Muhammad Peace Be Upon Him, one Holy Book- The Holy Qur'an, and one Holy Kaaba, then why people treat us discriminately and marginalize them? In order to respect God, one shall respect His Creature too. The God, Who created you people, is our Creator too. The respondents assured about them as true believers, true Muslims, having faith in truthfulness of Islam and commented very confidently "In contemporary world, Islam is the sole true religion", which is clear in the following verse:-

"Therefore, set right your face for the obedience of Allah being one devoted to Him only. The established pattern of Allah upon which He has created mankind. No change in the created things of Allah. This is the only right religion. But most of the people know not"' (Al-Qur'an, Surah Ar-Rum, 30:30) also translated as

"So set you (O Muhammad Peace Be Upon Him) your face towards the religion (of pure Islamic Monotheism) Hanif (worship none but Allah Alone). Allah's Fitrah (i.e. Allah's Islamic Monotheism) with which He has created mankind. No change let there be in Khalq-illah (i.e. the religion of Allah Islamic Monotheism): that is the straight religion, but most of men know not"' (Al-Qur'an, Surah Ar-Rum, 30:30)

They were aware of their religious rights, hence admitting that society gives them respectable place during religious preaching due to fear of God. However, as soon as 
they come out of sacred places, people start doing the stereotypical treatment expressing that khawaja saras are yet not fully acceptable to mainstream society. The respondents told that they understand it in such a way that they have place in worship and preaching where all are equal, hence they get less space in mainstream society wherein the patriarchy or male and female sex has a dominant prevailing status.

\section{Winding-Up Interviews}

At closing of interviews, respondents were expressed with gratefulness for sharing their personal views, experiences, and feelings. They were assured for confidentiality and presentation of data in such a manner that it may convince society to think about khawaja saras rationally and for building a good interaction and relationship. They shared that they were thinking that till now the third gender's true voice, message, feelings, experiences, perceptions and point of view is not communicated to mainstream globalized society therefore society need to re-understand them in true context. At conclusion of interview meeting almost every respondent paid thanks for giving them value, becoming their voice for highlighting their problems to society, for giving them encouragement, and confidence for speaking out their feelings, thoughts and experiences.

\section{Conclusions}

As a general principal, the individuals' internal conflicts and dichotomy do show that the external environment is in conducive and causing maladjustment problems. This is something very natural that birds of same feather flocks together and individuals of similar/alike characteristics adjust with each other, and regarding whom they feel different, they do not accept them. Male do have natural bond with female for having conjugal relations based on marriage and having children, which cannot be achieved through same sex marriage or a marriage of a male or of a female with hijra, consequently khawaja sara develop their own third gender community. The purpose of study was to know social identity and social interaction issues faced by hijra community while interacting with society in Pakistan. It was found that the khawaja sara experienced difficulties in society regarding becoming members of the families, acquiring education, living in mainstream society, having employment in organizations, due to the difference of their gender from mainstreamed genders i.e. males and females. Based on reality of their biological differences, neither males nor females accept them in their respective communities, consequently they formed a third gender community i.e. of khawaja sara, where in people of same biological sex, with similar/alike habits and (third) gender roles are there. They feel as deprived one, however they acknowledge the society's positivity toward them, hence they have some complaints too. Observation revealed that mostly less educated segments of 
society caught up by some myths regarding khawaja sara, hence rare have tried to know them. Khawaja Saras are passing through psychological problems or genuine handicaps beyond their control due to which they are in depressive situation. They said that they are more active members of society and can play a significant role in development of society but due to diverse fears they are unable to do so. If society focus on them, gives them their rights, support them, then they can become the productive members of society.

\section{Recommendations}

- The khawaja saras are human beings, should be treated accordingly by giving them right to live conducive life, social justice, civic rights, right to education, right to employment, right of identity, respect and religious rights.

- The Government, public and religious scholars shall create awareness regarding khawaja saras that they are equally respectful, productive and valuable members of society. Researchers should conduct research on such phenomena to create greater awareness at global level.

- The increased interaction and dialogue of khawaja saras with society through recorded interviews, discussions, press-releases, social media and television telecast etc. can create greater social acceptance and conducive environment for them in society, Insha Allah.

- Government should provide monetary assistance, employment, education and skills to them. Government shall legislate for protecting khawaja saras respect, survival, development and identity.

\section{References}

Abid. (July 15, 2009). Supreme Court Orders Equal Benefits for Transvestites. Retrieved from http://www.asylumlaw.org/docs/sexualminorities/Pakistan 071509.pdf, Retrieved on 05/04/2016.

Al-Bukhari, vol.7, book.72, no.773

Al-Bukhari, vol.7, book.72, no.774

Al-Tirmidhi, vol.4, ch.5, no. 1919)

Al Qur'an, 33:58.

Al Qur'an, 42:49-50. 
Al Qur'an, 30:30.

Ali, S. (2003). Khawajasaraoon Ki Dunya, July 6, Sunday Magazine, Nawa-eWaqt: p.27.

Badae, S. (1995). KitabulKhunsa.in K. M. Chawla (ed. 7, 751-756). Lahore: Markaze Tehqeeq Diyal Singh Trust Library.

Bartlett, N. H., Vasey, P.L. \& Bukowski, W. M. (2000). Is Gender Identity Disorder in Children a Mental Disorder? Sex Role, A Journal of Research, vol.43:11/12, pp.753-785.

Burke, J. (2013). Pakistan's Once-Ridiculed Transgender Community Fights Elections for First Time. Retrieved from http://www.guardian.co.uk/ world/2013/may/09/pakistan-transgender-elections-campaign-trail, Retrieved on 05/04/2016.

Chakrapani, D. V. (2010). Hijras/Transgender Women in India: HIV, Human Rights and Social Inclusion. United Nations Development Programme (UNDP), India.

Chaudhry, A. G., Khan, S. E. \& Ahmad, A. (2014). The Begging Hijras of Islamabad in the Age of Urbanization: An Anthropological Perspective, Science International, vol.26:5, pp.2553-2555.

Economic Times (Dec 23, 2009). People Defaulting on Bank Loans? Use Eunuch to Recover: Pak SC. Retrieved from articles. ecomonmictimes.indiatimes.com/ 2009-12-23/news/27653814_1_eunuchs-bank-loans-apex -court

Farid, T. et al. (2013). Response of Community Toward Gender Dysphorics. Green Journal of Social Sciences, vol.3:1, pp.58-66.

Gibbons J. L., Stiles D. A. \& Shkodriani G. M. (1991). Adolescents' Attitudes Towards Family and Gender Role: An International Comparison. Sex Roles, vol.25:Suppl 12, pp.625-643.

Hahm, Sonya Caroline. (2010). Striving to survive: human security of the Hijra of Pakistan. Conflict, Reconstruction and Human Security (CRS). Retrieved from http://hdl.handle.net/2105/8652

Jami, H. \& Kamal, A. (2015). Measuring Attitudes toward Hijras in Pakistan: Gender and Religiosity in Perspective. Pakistan Journal of Psychological Research, vol.30:1, pp.151-187 
Kessler, M. \& McKenna, W. (1978). Gender: An Ethno Methodological Approach. New York: John Wiley \& Sons.

Kumar, H. (2015, 13 Feb). Case Studies, Statistics and Survey on Hijras. Academike. Retrieved from http:/www.lawctopus.com/academike/casestudies-statistics-survey-hijras/, Retrieved 06/04/2016.

Nanda S. (1986). Cultural and Individual Dimensions of an Institutionalized Third Gender Role. Journal of Homosexuality, vol.11:3-4, pp.35-54.

Nanda, S. (1999). Neither Man Nor Woman: The Hijras of India, $2^{\text {nd }}$ ed. Wadsworth Pub. Co. Belmont, CA.

National Data Base Registration Authority (NADRA, Dec 16, 2010). Eunuch to be Provided Job by NADRA. Retrieved from http://www.nadra.gov.pk/ index.php?option=com_content\&view=article\&id=246:eunuchs-to-beprovided-jobs-bynadra\&catid=10:news-a-updates\&Itemid=20, Retrieved on $05 / 04 / 2016$.

Rasul, N. (2012). Democracy Slowly Spreads to the Margin of Pakistan Society. Retrieved from: http://nadiarasul.wordpress.com/2012/04/22/democrac yslowly-spreads-to-the-margins-of-pakistani-society/, Retrieved on 05/04/2016.

Sustainable Development Policy Institute (2014). Retrieved from https://www.sdpi.org/ policy_outreach/event_details386-2014.html, Retrieved on 05/04/2016.

Talwar, R. (1999). The Third Sex and Human Rights. New Delhi: Gyan Publishing House.

Teh, Y. K. (2001). Mak Nyahs (Male Transexualism) in Malaysia: The Influence of Culture and Religion on Their Identity. International Journal of Transgenderism, 5(3). Retrieved from http://www.Symposion.com/ ijt/ijtvo05no03 04.htm, Retrived on 05/04/2016.

Udry, J. R. (1994). The Nature of Gender. Demography, vol.31:4, pp.561-73.

Zafar, R. (2004, Sep 19). Hijroon Ki Pursarar Duniya: Dukhon Ki Chakki Mein Pisnay Walay Aik Tabkay Ki Daroon-en Khana Dilchasp Kahani. Jang: Sunday Magazine. 
Dr. Mamoon Khan Khattak is an Assistant Professor \& Incharge Chairperson in the Department of Social Work \& Sociology, Kohat University of Science \& Technology (KUST), Kohat, Pakistan.

Ehtisham Ul Haq is Lecturer in the Department of Social Work \& Sociology, Kohat University of Science \& Technology (KUST), Kohat, Pakistan. 